\title{
Molecular cloning, characterization and gene expression of a water deficiency and chilling induced proteinase inhibitor I gene family from sweet potato (Ipomoea batatas Lam.) leaves is
}

\author{
Hui-Yi Wang, Ya-Chen Huang, Shih-Fung Chen, Kai-Wun Yeh* \\ Department of Botany, National Taiwan University, No. 1, Sec. 4, Roosevelt Road, Taipei 106, Taiwan, ROC
}

Received 3 January 2003; received in revised form 3 March 2003; accepted 4 March 2003

\begin{abstract}
A 7-kDa-proteinase inhibitor, designated SPLTI (Sweet Potato Leaf Trypsin Inhibitor) was partially purified from sweet potato (Ipomoea batatas Lam.) leaves under water deficiency. The N-terminal amino acid sequence was determined and used to design two overlap degenerate primers for isolation of the SPLTI gene. Two full-length cDNA clones encoding proteinase inhibitor I (PI-I), designated SPLTI- $a$ and SPLTI- $b$, were isolated. Both SPLTI- $a$ and SPLTI- $b$ are $98 \%$ identical to each other in both levels of nucleotide and amino acid sequence. Different from most of PI-Is that exhibit chymotrypsin-inhibitory activity, SPLTI from sweet potato and recombinant SPLTI-a overexpressed in Escherichia coli showed mainly trypsin-inhibitory activity. Furthermore, sitedirected mutagenesis analysis of an $\mathrm{Arg}^{46}-\mathrm{G} 1 \mathrm{u}^{47}$ motif of SPLTI-a, based on amino acid sequence alignment with other PI-Is, indicated that $\mathrm{Arg}^{46}-\mathrm{G} 1 \mathrm{u}^{47}$ of SPLTI is a novel reactive site for PI-I family conferring the trypsin-specific inhibitory activity. Using SPLTI- $a$ as a probe, we found that SPLTI gene exhibited a leaf-specific expression pattern. Additionally, this was the first report that the SPLTI genes were up-regulated by water deficiency and chilling as well as osmoticant treatments in the PI-I family in plants. As other PIs, the SPLTI transcripts were induced by wounding and also by exogenous applications of abscisic acid and methyl jasmonate; however, accumulation of the wound-induced transcripts were restricted locally in the injured leaves, but not systemically. These distinct expression patterns provided a new insight to the regulation of PI-I gene family in response to environmental stresses. Our results suggested that SPLTI could participate in defense systems against invasions of insects or bacteria as other PI-Is. Moreover, it may play a role against environmental stresses through regulation of endogenous proteolytic activities during leaf development.
\end{abstract}

(C) 2003 Elsevier Science Ireland Ltd. All rights reserved.

Keywords: Proteinase inhibitor I (PI-I); Water deficiency; Chilling stress; Systemic wound response

\section{Introduction}

Proteinase inhibitors (PIs) are classified into serine-, cysteine-, aspartic-, and metallo-PIs, according to the

Abbreviations: ABA, abscisic acid; JA, jasmonic acid; MeJA, methyl jasmonate; PEG, polyethylene glycol; PI-I, proteinase inhibitor I; RWC, relative water content; SA, salicylic acid; SPLTI, sweet potato leaf trypsin inhibitor.

The nucleotide sequences of SPLTI- $a$, SPLTI- $b, g S P L T I-1$ and gSPLTI-2 reported in this paper have been deposited to GenBank under accession numbers of AF330700, AF404833, AF330701 and AF330702, respectively.

* Corresponding author. Tel.: +886-2-2363-0231x2676; fax: +8862-2362-2703.

E-mail address: ykwbppp@ms.cc.ntu.edu.tw (K.-W. Yeh). types of proteinase that they inhibit. In higher plants, PIs are shown to be particularly abundant in storage organs [1], such as seeds [1,2], tubers [3] and endosperm $[4,5]$. A large body of evidence indicated that PIs functioned as storage proteins [1], regulate the endogenous proteinase activities [6], and suppress the exogenous proteinase activities from pathogens and pests $[7,8]$. The defensive role of PIs was demonstrated by the observations that transgenic plants that overexpressing PIs are more resistant to insect attack than the control plants [9]. Four types of PIs were found to accumulate rapidly in leaves in response to mechanical wounding or insect chewing [9-11], suggesting a direct role of PIs in plant protection. 
Serine PIs were firstly shown to inhibit the growth of larvae from several lepidopteran insect species [12]. The serine PIs are subdivided into eight distinct families, based on the protein structure of sequence homology, location of disulfide bridge pairing, and the position of the reactive site $[1,13]$. Proteinase inhibitor I (PI-I) family is one of the most widespread family of serine PIs, present in numerous families of plants, yeast and a lower animal, the leech Hirudo medicinalis [1]. PI-I was firstly isolated from potato tuber [3]. Homologous proteins with inhibitory properties against serine endopeptidases with specificities have been subsequently characterized [14]. Two distinct biochemical features are found in members of PI-I protein family, including the lack of intramolecular disulfide bonds required for stabilization of their structure and the wide range of inhibitory activity against chymotrypsin, trypsin, elastase, cathepsin G, bacterial subtilisin, Streptomyces griseus endopeptidase, and yeast proteinase B [14].

The PI-I proteins accumulated abundantly in storage organs $[1,2,5]$ or in unripen fruit of wild tomato under developmental regulation [15]. PI-I proteins are also inducible in vegetative leaves following insect attacks or other severe wounding $[16,17]$. The studies of systemic accumulation of PI-I proteins in response to herbivore attack were led to the identification of the systemic wound signal systemin and other signaling components in tomato $[11,18,19]$. Systemin was shown as a primary wound signal released at wound site by chewing herbivores, and subsequently interacted with its receptor to initiate a complex cascade of intracellular events, including synthesis of jasmonic acid (JA) for PI-I genes activation [11].

Although the signal transduction pathway of the wound response has been studied extensively, the information about gene expression of PIs in response to other environmental stresses, such as water deficiency and chilling, are very limited. Up to date, only a few examples of $P I$ genes were shown to be responsive to water deficiency [20] or to both water deficiency and chilling stress [21,22], however, none of them was shown belonging to PI-I family. Drought stress accelerated leaf senescence with the increase of endogenous proteinase activity [20]. Endogenous proteinase induced by water deficiency or chilling stress was reported in tomato [23], cowpea [24] and common bean [25]. These studies indicated that proteinases were involved in the protein degradation processes during the drought or chilling stress. Downing et al. [20] suggested that a putative Kunitz family of serine proteinase inhibitor induced by drought stress could act as a regulator of endogenous proteinase activity.

In our previous study, a serine proteinase inhibitor with trypsin-inhibitory activity, designated SPLTI, was detected in sweet potato leaves (Ipomoea batatas L. cv. Tainung 57) [26]. We are particularly interested in the study of the regulation of the SPLTI genes expression under environmental stresses, especially water deficiency and chilling stress. In this report, the SPLTI genes were characterized and its products were identified as homologues of PI-I family. Moreover, recombinant protein activity of SPLTI overexpressed in Escherichia coli and site-directed mutagenesis analyses of its novel reactive site of SPLTI correlated with the specificity of trypsininhibitory activity, instead of most of the other PI-I family members with chymotrypsin-inhibitory activity. We reported here the possible roles of the SPLTI genes, which were the first member of PI-I family genes upregulated by both stresses of water deficiency and chilling in plants.

\section{Materials and methods}

\subsection{Plant materials}

Sprouting shoots of Sweet potato (Ipomoea batatas L. cv. Tainung 57) were cut from tuberous roots, and incubated in distilled water to induce the formation of adventitious roots at $28^{\circ} \mathrm{C}$ under $16 \mathrm{~h}$ light $(115 \pm 15$ $\left.\mu \mathrm{mol} \mathrm{m} \mathrm{m}^{-2} \mathrm{~s}^{-1}\right) / 8 \mathrm{~h}$ dark period for 3-5 days. Then, rooting shoots were transferred and grown in vermiculite for one week under the same conditions. Approximately shoots with same height were treated with various stresses as described below. Three individual plants were used in each treatment.

\subsection{Stress treatments}

For water-stress treatment, sweet potato shoots were grown withholding water supply for 5 days. Unexpanded young leaves $(0.7-1.5 \mathrm{~cm}$ in length), fully expanded leaves $(6.0-7.0 \mathrm{~cm}$ in length), stems, roots and tubers were harvested separately for total RNA extraction. For osmotic stress, high salt, temperature stress, and phytohormone treatments, fully expanded leaves $(6.0-7.0 \mathrm{~cm}$ in length) were harvested to extract total RNA. Regarding to the osmotic stress, shoots with adventitious roots were transferred to solutions with $10 \%(\mathrm{w} / \mathrm{v})$ polyethylene glycol (PEG) 6000 or $300 \mathrm{mM}$ sorbitol for 1 week. For high salt treatment, shoots were incubated $24 \mathrm{~h}$ in $300 \mathrm{mM} \mathrm{NaCl}$ solution. For temperature stress treatment, plants grew in vermiculite were moved into a growth chamber at $42{ }^{\circ} \mathrm{C}$ for $6 \mathrm{~h}$ incubation or into a $10{ }^{\circ} \mathrm{C}$ growth chamber with normal light intensity $\left(115 \pm 15 \mu \mathrm{mol} \mathrm{m}{ }^{-2} \mathrm{~s}^{-1}\right)$ for $48 \mathrm{~h}$. When phytohormone treatments were applied, shoots with adventitious roots were then subjected to $50 \mu \mathrm{M}$ abscisic acid (ABA) or $50 \mu \mathrm{M}$ methyl jasmonate (MeJA) solution for $6 \mathrm{~h}$. For wound treatment, the third fully expanded leaf $(6.0-7.0 \mathrm{~cm}$ in length) of the shoot was multiple wounded by scissors. Wounded-, upper- and 
lower-unwounded leaves were sampled separately after 6 $\mathrm{h}$ of wound treatment.

To investigate the time course response of SPLTI transcripts in response to water deficiency and rehydration treatments, plants in different pots were treated by withholding water supply for 1,3 or 5 days; on day 5 , plants were re-watered for additional 1,3 or 5 days. The unexpanded young leaves $(0.7-1.5 \mathrm{~cm}$ in length) and the third fully expanded leaves $(6.0-7.0 \mathrm{~cm}$ in length) were harvested at the time interval as described above.

\subsection{Measurement of relative water content}

The relative water content (RWC) of leaf was measured to indicate the dehydration extent [20] after water deficiency or rehydration treatments. Plants were treated and harvested as described above. The immediately detached leaf was weighed and designated as $\mathrm{W}_{\mathrm{F}}$. Then, the leaf was imbibed in distilled water for $40 \mathrm{~h}$ at $4{ }^{\circ} \mathrm{C}$ under darkness and the weight of the leaf was designated as $\mathrm{W}_{\mathrm{s}}$. $\mathrm{W}_{\mathrm{D}}$ represented the dry weight of the leaf desiccated in an air flow oven at $65^{\circ} \mathrm{C}$ for $72 \mathrm{~h}$. RWC was calculated according to the equation as follows:

$\left[\left(\mathrm{W}_{\mathrm{F}}-\mathrm{W}_{\mathrm{D}}\right) /\left(\mathrm{W}_{\mathrm{S}}-\mathrm{W}_{\mathrm{D}}\right)\right] \times 100$

\subsection{Protein purification}

The procedures for protein purification were all conducted at $4{ }^{\circ} \mathrm{C}$. Plant tissue was pulverized in liquid nitrogen using a mortar and pestle until a fine, homogenous powder was obtained. Then, the powder was mixed thoroughly with extraction buffer composed of 50 $\mathrm{mM}$ Tris $-\mathrm{HCl}(\mathrm{pH} 8.0), 0.3 \mathrm{M} \mathrm{NaCl}, 10 \%$ (w/v) sucrose, $10 \mathrm{mM} \mathrm{L}$-ascorbic acid, 1\% (v/v) dimethylsulfoxide, 3 $\mathrm{mM}$ phenylmethylsulfonyl fluoride, $0.2 \%(\mathrm{v} / \mathrm{v})$ Triton X100 , and $1 \%(\mathrm{v} / \mathrm{v}) \beta$-mercaptoethanol. Crude protein extract was fractionated by $60 \%$ ammonium sulfate. The precipitate was pelleted, dissolved in $10 \mathrm{mM}$ Tris $-\mathrm{HCl}$ buffer ( $\mathrm{pH}$ 8.0) and dialyzed against the same buffer. To enrich the protein fraction with trypsin-inhibitory activity, the proteins were then mixed thoroughly with DEAE Sephadex (Pharmacia, LKB) gel beads preequilibrated with $10 \mathrm{mM}$ Tris- $\mathrm{HCl}$ buffer $(\mathrm{pH} 8.0)$. After washing the beads with $10 \mathrm{mM}$ Tris $-\mathrm{HCl}$ buffer ( $\mathrm{pH} 8.0$ ), the proteins were eluted with $10 \mathrm{mM}$ Tris $-\mathrm{HCl}$ buffer $(\mathrm{pH} 8.0)$ containing $0.1 \mathrm{M} \mathrm{NaCl}$. The eluted proteins were separated on $15 \%$ SDS-PAGE [27] and subjected to the trypsin-inhibitory activity assay.

\subsection{Trypsin-inhibitoty activity assay}

Trypsin-inhibitory activity was analyzed on a polyacrylamide gel with the method modified from Chan and DeLumex [28]. The crude extracts or partially purified proteins from sweet potato leaves were dissolved in the sample buffer $(2 \%(\mathrm{v} / \mathrm{v})$ SDS, $10 \%(\mathrm{v} / \mathrm{v})$ glycerol, $62.5 \mathrm{mM}$ Tris-HCl, $\mathrm{pH}$ 6.8). After electrophoresis, to remove the SDS, the gel was incubated in a buffer containing $10 \mathrm{mM}$ Tris- $\mathrm{HCl}$ buffer ( $\mathrm{pH}$ 7.4) and $25 \%(\mathrm{v} / \mathrm{v}) 2$-propanol with shaking gently for $30 \mathrm{~min}$, and then in $10 \mathrm{mM}$ Tris- $\mathrm{HCl}$ buffer $(\mathrm{pH}$ 8.0) for another $30 \mathrm{~min}$ to renature the proteins. Let the gel reacts with trypsin solution $\left(40 \mu \mathrm{g} \mathrm{ml}^{-1}\right.$ bovine trypsin (Sigma) in $50 \mathrm{mM}$ Tris $-\mathrm{HCl}(\mathrm{pH} 8.0)$ and $50 \mathrm{mM}$ $\mathrm{CaCl}_{2}$ ) for $40 \mathrm{~min}$. After discarding the trypsin solution, the gel was developed with freshly prepared substratedye solution for $25 \mathrm{~min}$ at room temperature, which consisted of $2.5 \mathrm{mg} \mathrm{ml}^{-1} N$-acetyl-DL-phenylalanine $\beta$ naphthyl ester (Sigma) in dimethylformamide and tetrazotized o-dianisidine dye solution $\left(0.5 \mathrm{mg} \mathrm{ml}^{-1}\right.$ in $50 \mathrm{mM}$ Tris $-\mathrm{HCl}(\mathrm{pH} 8.0)$ and $50 \mathrm{mM} \mathrm{CaCl}$ ). Acetic acid $(10 \%(\mathrm{v} / \mathrm{v}))$ was added to stop the reaction of color development. The clear zones appeared on the gel indicate the proteins with trypsin-inhibitory activity.

\subsection{N-terminal amino acid sequence determination}

To determine the N-terminal amino acid sequence of SPLTI protein, the enriched protein fractions with trypsin-inhibitory activity was denatured completely. Therefore, partially purified proteins were dissolved in $\beta$-mercaptoethanol-containing sample buffer and heated at $100{ }^{\circ} \mathrm{C}$ for $3 \mathrm{~min}$. The denatured proteins were separated on duplicate $13.3 \%$ Tricine-SDS-PAGEs as described by Schägger and von Jagow [29]. One of them was stained with Coomassie brilliant Blue R-250. The proteins on the other gel were then blotted onto PVDF membrane (Immobilon ${ }^{\mathrm{TM}}-\mathrm{P}$, Millipore, MA). Membrane slice containing protein of interest was excised and subjected to $\mathrm{N}$-terminus determination by Edmen degradation analysis with an automatic amino acid sequencer (Model 4774/120A, Applied Biosystem, USA).

\subsection{Molecular cloning of the SPLTI genes}

To isolate the SPLTI cDNA, based on the N-terminal amino acid sequence (KTSWPELVGV) of SPLTI (refer to Fig. 3), two overlap nested degenerate primers were designed, GSP-1, 5'-A(A/G)AC(A/G)TCGTGGCC(A/ G)GAAC-3' and GSP-2, 5'-TGGCC(A/G)GAACT(T/ A)GTGG-3'. Total leaf RNA was extracted from waterdeficit sweet potato ( $85 \%$ RWC) using TRIZOL Reagent (Gibco-BRL) following the manufacturer's protocol. The poly $(\mathrm{A})^{+}$RNA were fractionated with mRNA Purification Kit (Amersham Pharmacia Biotech) according to the manufacturer's instructions. First strand cDNAs were synthesized from $1 \mu \mathrm{g}$ poly (A) ${ }^{+}$ RNA with Avian Myeloblastosis Virus reverse tran- 
scriptase (AMV-RTase) (Promega, WI) using oligo$\mathrm{d}(\mathrm{T})_{12-18}$ Primer (GibcoBRL, MD) as primers at $48{ }^{\circ} \mathrm{C}$ for $45 \mathrm{~min}$. The primers (GSP-1, GSP-2) were used subsequently in the PCR reactions. The PCR reaction was commenced with Taq DNA polymerase (Promega, WI) by DNA Thermal Cycler 480 (Perkin Elmer). The touchdown PCR program was used as following: 5 cycles at $94{ }^{\circ} \mathrm{C}$ for $30 \mathrm{~s}, 55^{\circ} \mathrm{C}$ for $30 \mathrm{~s}, 72{ }^{\circ} \mathrm{C}$ for $30 \mathrm{~s} ; 5$ cycles at $94{ }^{\circ} \mathrm{C}$ for $30 \mathrm{~s}, 52^{\circ} \mathrm{C}$ for $30 \mathrm{~s}, 72^{\circ} \mathrm{C}$ for $30 \mathrm{~s}$; followed by 32 cycles at $94{ }^{\circ} \mathrm{C}$ for $30 \mathrm{~s}, 47^{\circ} \mathrm{C}$ for $30 \mathrm{~s}, 72{ }^{\circ} \mathrm{C}$ for $30 \mathrm{~s}$, and a final extension at $72{ }^{\circ} \mathrm{C}$ for 10 min. The amplified fragments were purified from agarose gel and ligated into pGEM-T Easy Vector (Promega, WI) for DNA sequencing. Further extension of the $5^{\prime}$ - and $3^{\prime}$-end of full-length cDNAs was completed by SMART ${ }^{\mathrm{TM}}$ RACE cDNA Amplification Kit (Clontech, CA) according to the user manual. To confirm the fidelity of the cDNA sequence, several clones of SPLTI- $a$ or SPLTI- $b$ obtained from independent PCR amplifications showed the same nucleotide sequence after DNA sequence analysis.

To amplify the genomic clone of SPLTI, sweet potato genomic DNA was extracted using DNAZOL Reagent (GibcoBRL, MD) according to the manufacturer's protocol. Two gene-specific primers were used to conduct PCR reaction. The gene-specific primers (5'-AACCACAAAAGAGAGGCAAACATCAAAG-3' and 5'GAAAGCAGATGTTTACTTGCCACTC-3') were designed from the 5'-and 3 '-end sequence of SPLTI-a cDNA clone (refer to Fig. 2), respectively. Sequences used for alignments were identified from BLAST searches of DDBJ/EMBL/GenBank databases. Alignment of the amino acid or nucleotide sequence was generated by the Pileup and Prettybox programs of UWGCG program suite version 10.0 (Wisconsin) through the NHRI of Taiwan at Nankang, Taipei.

\subsection{Genomic DNA blot and RNA blot analysis}

Southern and Northern blot hybridization followed the methods in the Molecular Cloning [30a]. Genomic DNA was extracted as described as above. Ten microgram of genomic DNA was completely digested with restriction enzyme, then fractionated on a $0.8 \%$ agarose 1X TAE gel and blotted onto the nylon membrane (Immobilon ${ }^{\mathrm{TM}}-\mathrm{Ny}+$, Millipore, MA). Total RNA was prepared as described above from different tissues or stress-treated leaves of sweet potato. Five micrograms of total RNA was fractionated on a $1.0 \%$ formaldehydedenatured agarose gels and transferred to the nylon membrane (Immobilon ${ }^{\mathrm{TM}}-\mathrm{Ny}+$ ). The filters were prehybridized by QuickHyb solution (Stratagene) with 250 $\mu \mathrm{g} \mathrm{ml}{ }^{-1}$ denatured salmon sperm DNA at $68^{\circ} \mathrm{C}$ for at least $30 \mathrm{~min}$. Hybridization was performed at $68{ }^{\circ} \mathrm{C}$ for $2 \mathrm{~h}$ in the same solution using a ${ }^{32} \mathrm{P}$-dCTP-labeled $S P L T I-a$ cDNA as a probe $\left(>10^{7} \mathrm{cpm}\right.$ specific activity, cpm/ug DNA). The probes were labeled with $\alpha-\left[{ }^{32} \mathrm{P}\right]-$ dCTP (3000 Ci mmol ${ }^{-1}$, Perkin Elmer) using a random prime labeling system Rediprime II kit (Amersham Pharmacia Biotech). Then, the filters were washed three times in $2 \times \mathrm{SSC}, 0.1 \% \mathrm{SDS}$ at room temperature for 10 min and two times in $0.1 \times \mathrm{SSC}, 0.1 \% \mathrm{SDS}$ at $56^{\circ} \mathrm{C}$ for $20 \mathrm{~min}$.

\subsection{Expression and purification of recombinant SPLTI}

To study the activity of SPLTI in vitro, we amplified the 228-bp coding region by PCR, using oligonucleotides that introduced a $B a m \mathrm{H}$ I and an $E c o$ R I restriction site at the $\mathrm{N}$ - and $\mathrm{C}$-terminal ends, respectively. The PCR condition was 30 cycles at $94{ }^{\circ} \mathrm{C}$ for 30 s, $54{ }^{\circ} \mathrm{C}$ for $30 \mathrm{~s}, 72{ }^{\circ} \mathrm{C}$ for $30 \mathrm{~s}$ and an extension at $72{ }^{\circ} \mathrm{C}$ for $10 \mathrm{~min}$. Amplified fragments were sequenced and ligated into the Bam $\mathrm{H}$ I and Eco R I sites of pGEX-2T vector (Pharmacia) behind the glutathione $S$-transferase (GST) gene. The construct, pGEX-2T-SPLTI, was introduced into $E$. coli strain XL1-Blue. The induction and purification of GST-SPLTI fusion protein were carried out as described by Yao et al. [31], except the induction temperature was under $25^{\circ} \mathrm{C}$ for $6 \mathrm{~h}$. For quantitative analysis of trypsin- and chymotrypsininhibitory activity, the purified GST-SPLTI fusion proteins were subjected to thrombin (Sigma) digestion at $16{ }^{\circ} \mathrm{C}$ for $16 \mathrm{~h}$.

\subsection{Site-directed mutagenesis}

In order to confirm the deduced reactive site ( $\mathrm{Arg}^{46}$ $\mathrm{G}^{4} \mathrm{u}^{47}$ ) of SPLTI, three amino acid substitution mutants were constructed, using the overlap extension mutagenesis method [30b], one carrying the mutation R46M, the second carrying E47K, and a double mutation R46M/ E47D. Three oligonucleotides were designed for PCR reactions to replace the individual residue (R46M, 5'CGAAACAATGGAGTATATCTT-3'; E47K, 5'CGAAACACGGAAGTATATCTT-3') or the two residues (R46M/E47D, 5'-CCGAAACAATGGACTATATCTTTG- ${ }^{\prime}$ ). The underlines indicated the mutated residues. The restriction sites, $B a m \mathrm{H}$ I and $E c o$ R I, were introduced into the unique primers. The PCR program was performed for 30 cycles at $94{ }^{\circ} \mathrm{C}$ for $30 \mathrm{~s}, 54{ }^{\circ} \mathrm{C}$ for $30 \mathrm{~s}, 72{ }^{\circ} \mathrm{C}$ for $30 \mathrm{~s}$, and an extension at $72{ }^{\circ} \mathrm{C}$ for 10 min. Amplified fragments were sequenced and ligated into the $B a m \mathrm{H}$ I and Eco R I sites of pGEX-2T vector (Pharmacia) behind the GST gene. The expression and purification of mutated recombinant SPLTI were followed the methods as described above. 


\subsection{Quantitative analysis of trypsin- and chymotrypsin-} inhibitory activity

The quantitative analysis of trypsin- and chymotrypsin-inhibitory activity of recombinant SPLTI was conducted according to the procedures described previously [31]. The purified recombinant SPLTI was incubated with trypsin (Sigma) or chymotrypsin (Sigma) at a molar ratio of 1:1. $N_{\alpha}$-benzoyl-DL-arginine $p$-nitroanilide (BAPNA, Sigma) and $N$-succinyl-Ala-Ala-ProPhe $p$-nitroanilide $\left(\mathrm{SA}_{2} \mathrm{PFNA}\right.$, Sigma) were used as substrates for trypsin and chymotrypsin, respectively. The original relative activity was defined by incubating the proteinases with substrates for $30 \mathrm{~min}$ at $37^{\circ} \mathrm{C}$. The residual relative activity was the activity that the proteinase was incubated with recombinant SPLTI at $37^{\circ} \mathrm{C}$ for $10 \mathrm{~min}$, and then added the substrate for additional $20 \mathrm{~min}$. The absorbance at $410 \mathrm{~nm}$ of the reaction mixture was measured. The percentage inhibition of trypsin- and chymotrypsin-inhibitory activities by recombinant SPLTI was calculated as described previously [31].

\section{Results}

\subsection{Purification and N-terminal sequencing of SPLTI protein from sweet potato leaves}

We identified a 14-KDa protein, designated SPLTI, with trypsin-inhibitory activity (Fig. 1A, lane 2) from sweet potato leaves under water deficiency for 5 days. The SPLTI was enriched from crude protein extracts by fractionation with $60 \%$ ammonium sulfate precipitation and purified through DEAE column chromatography. The partially purified proteins were then analyzed for trypsin-inhibitory activity (Fig. 1A, lane 3). Protein extracts were dissolved in the sample buffer without $\beta$ mercaptoethanol prior to electrophoresis when performing this assay. In order to break the potential disulfide bonds, the partially purified proteins were further denatured by heating in the SDS sample buffer with $\beta$ mercaptoethanol at $100{ }^{\circ} \mathrm{C}$. A major band of approximate $7 \mathrm{kDa}$, designated denatured SPLTI, was observed by SDS-PAGE with Coomassie Blue staining (Fig. 1B, lane 1). To verify if the 7-KDa proteins came from the 14-kDa proteins, both 7- and 14-KDa proteins were transferred onto the PVDF membranes for $\mathrm{N}$ terminal amino acid sequence analysis by Edman degradation. The first 18 amino acid residues were found to be the same in both 7- and 14-kDa proteins, indicating that SPLTI can form as a dimer in sweet potato leaves (Fig. 1A). A homology search against DDBJ/EMBL/GenBank databases showed that SPLTI contained a TSWPELVG motif homologous to PI-I family of serine PIs.

\section{(A)}

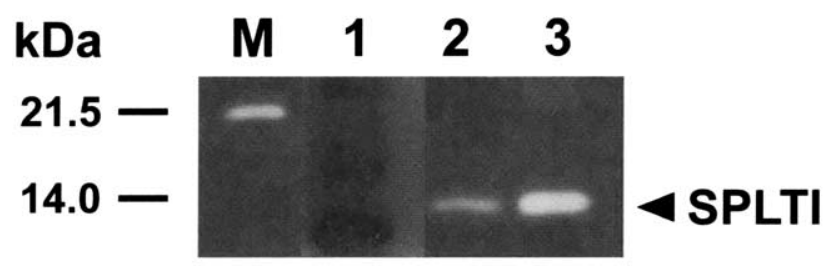

(B)

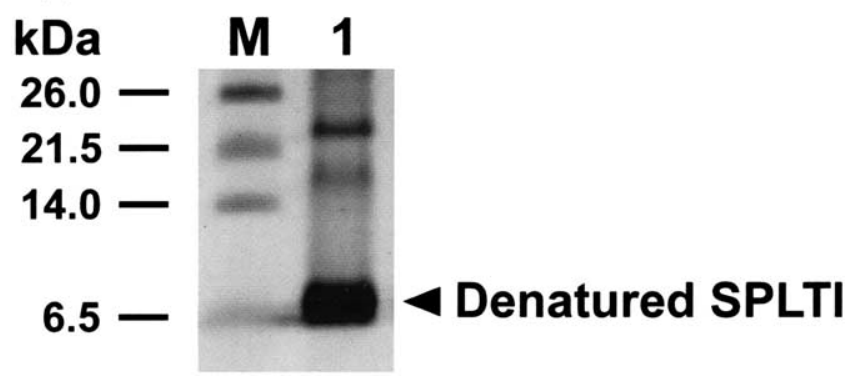

Fig. 1. (A) Trypsin-inhibitory activity assay of proteins from sweet potato leaves. Protein samples dissolved in sample buffer without $\beta$ mercaptoethanol were resolved on 15\% SDS-PAGE, and then assayed for trypsin-inhibitory activity. M, protein molecular markers (BioLabs, MA) with the $21.5-\mathrm{kDa}$ soybean trypsin inhibitor. Lane 1, 200 $\mu \mathrm{g}$ of crude protein extract from control leaves. Lane 2, $200 \mu \mathrm{g}$ of crude protein extract from leaves under 5 day of water deficiency. Lane 3, 10 $\mu \mathrm{g}$ of partially purified SPLTI protein. (B) Coomassie Brilliant Blue R250 staining of the denatured SPLTI. Ten micrograms of partially purified protein were analyzed on $13.3 \%$ Tricine-SDS-PAGE after heating at $100{ }^{\circ} \mathrm{C}$ for $10 \mathrm{~min}$ with $\beta$-mercaptoethanol. $\mathrm{M}$, protein molecular markers.

\subsection{Isolation and characterization of the SPLTI gene encoding a homolog of the PI-I family}

For isolation of the SPLTI cDNAs, two nested degenerate primers were designed from the SPLTI Nterminal amino acid sequence and were used for reverse transcriptase-PCR followed by $5^{\prime}$ - and $3^{\prime}$-rapid amplification of cDNA ends (RACE). Two cDNA clones, SPLTI- $a$ (432 bp) and SPLTI-b (429 bp), were obtained. Fig. 2A shows the nucleotide and the deduced amino acid sequences of SPLTI- $a$ cDNA clone. A single nucleotide difference was found in the open reading frames (ORF) of SPLTI- $a$ and SPLTI-b (Fig. 2B). In the untranslated region, both sequences also had differences at four locations. Additionally, by PCR using the primers designed from SPLTI- $a$ cDNA we isolated two genomic clones, $g S P L T I-1$ (519 bp) and gSPLTI-2 (524 bp), consisting of an 87- and a 101-bp intron within the ORFs, respectively (Fig. 2B). These four clones i.e. two cDNAs and two genomic clones, represented four independent clones with high similarity in the nucleotide sequences. Moreover, the observation of genomic DNA blot using SPLTI- $a$ cDNA as a probe showed six to seven prominent hybridization bands (data not shown), indicating that SPLTI was encoded by a small gene family. The ORFs of the cDNAs are 213-bp 
A.

1 AACCACAAAAGAGAGGCAAACATCAAAGAAAAACCCAATTAACCTCCAAACATCAAGAAA

61 ATGCAGCGCATCACCGACGGTAAGACTAGCTGGCCGGAACTGGTGGGAGTGGACGCATTT

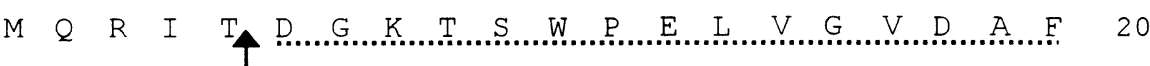

121 TTAGCAAAATCTACGATTGAGAAAGAAAACAGCGACTTGTATGTTGTGTTTCTTTTCCAA $\begin{array}{lllllllllllllllllll}\text { L............. } & \text { S } & \text { T } & \text { I } & E & \text { K } & E & \text { N } & \text { S } & \text { D } & \text { L } & \text { Y } & \text { V } & \text { V } & \text { F } & \text { L } & \text { F } & Q & 4\end{array}$

181 GGCTGCCCCGAAACACGGGAGTATATCTTTGACCGAGTTCGTCTTATCGTTGACTGTAGC $\begin{array}{llllllllllllllllllllll}G & C & P & E & T & R & E & Y & I & F & D & R & V & R & L & I & V & D & C & S & 60\end{array}$

241 AACGTTGTTATAAGAACTCCGTCGATTGGCTAGGTGGGAGATCATTATATTCTATTCTGA $\begin{array}{llllllllllllll}N & \text { V } & \text { V } & \text { I } & \text { R } & \text { T } & \text { P } & \text { S } & \text { I } & G & * & 70\end{array}$

301 ATGAAGTAGATGTTGTAAACCCTACCTGCCCCAACAATAAATAATGTACATTCATGGACT

361 TCATGATGAACTCCATGTTGGACTATGAATCCTTTATCCTTAAATAAGAGTGGCAAGTAA

421 ACATCTGCTTTC

1

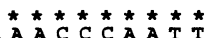

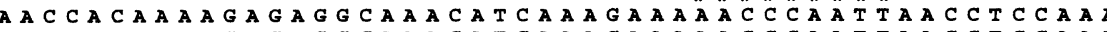

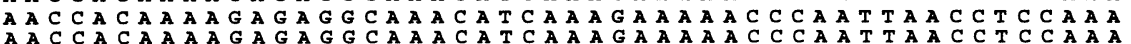

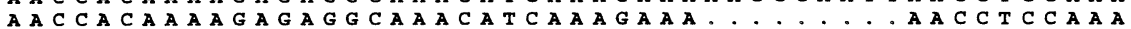

51

SPLTI-a

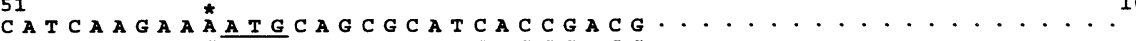

SPLTI-b CATCAAGA A GATGCA G C G CATCACC GACG

CATCA GA GATCAGCGCATCACCGACGgtatata

gSPTI-2 CA TCA A A A GTGCAGCGCATA 101

SPLTI-a

SPLTI-D

$\ldots \ldots \ldots \ldots \cdots \cdots \cdots \cdots \cdots$

ct $t c t c t g a t$ a 151

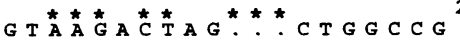

SPLTI-a

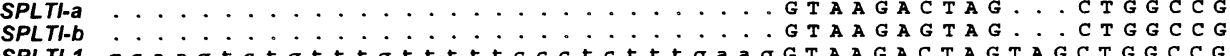

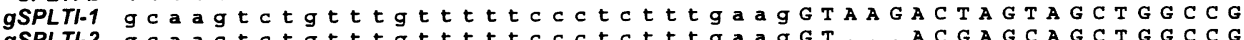

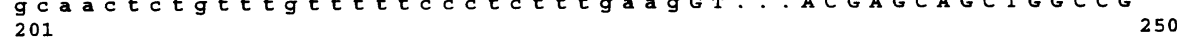

SPLTI-a GA C TGGTGGGAGTGGACG CATTTTTAGCAAAATCTACGATTGAGAAAGA

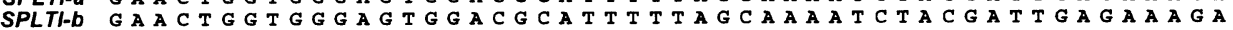

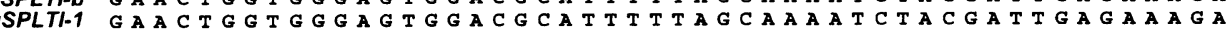

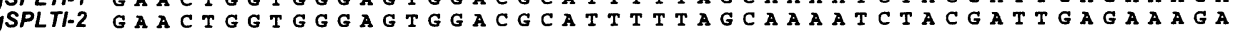
251 A C G C A CTTGT

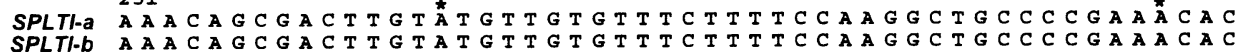

gSPLTI-1 A C A G C GACTTGTTT T T T G T G T T T C T T T TCCAAGGCTGCCCCGAATCAC

gSPLTI-2 A A A C A C GACTTGTATGTTGTGTTTCTTTTCCAAGGCTGCCCCGAAACAC

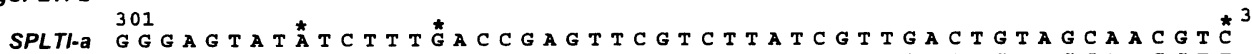

SPLTI-A GGGAGTATATCTTTGACCGAGTTCGTCTTATCGTTGACTGTAGCAACGTC

SPLTI-b G G G A G T A T A T C T T T GACCGAGTTCGTCT TA T C G T T G A C T G T A GCA A C G T T

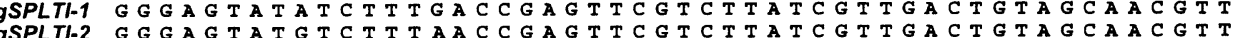
35I AG TATGTCTTTAACC GAGTTCGTCTIATCGTTGACTGTAGCAACGTT 400

SPLTI-a GTTATAAGAACTCCG GTTATAAGAACTCCGTCGATTGGCTAGGTGGGAGATCATTATATTCTATT GTTATAAGAACTCCGTCGATTGGCTAGGTGGGAGATCATTATATTCTATT 401

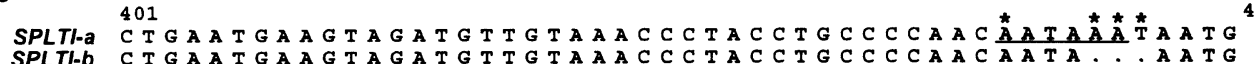

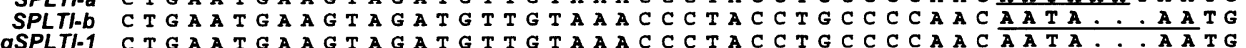

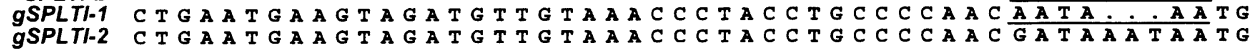
451

SPLTI-a TACATTCATGGACTTCATGATGAACTCCATGTTGGACTATGAATCCTTTA

SPLTI-b TACATTCATGGACTTCATGATGAACTCCATGTTGGACTATGAATCCTTTA

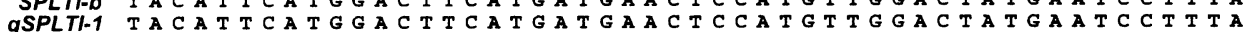

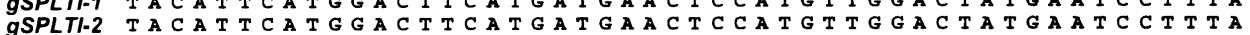
501 A T T CA T G GACTTCATGATGAACTCCAT T T G 536

SPLTI-a TC C T T A A T TA GA G T G G CAAGTAAACA T C T G C T T T C

SPLTI-b TC TCTTAAATAAGAGTGGCAAGTAAACA TC T G C T T T C

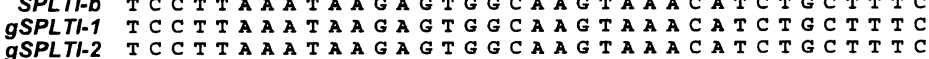

Fig. 2. 
SPLTI

potato

Tomato

Barley

Maize

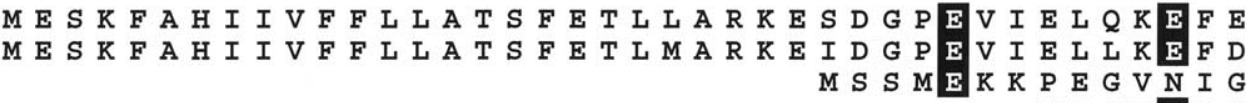
M S S T E C G
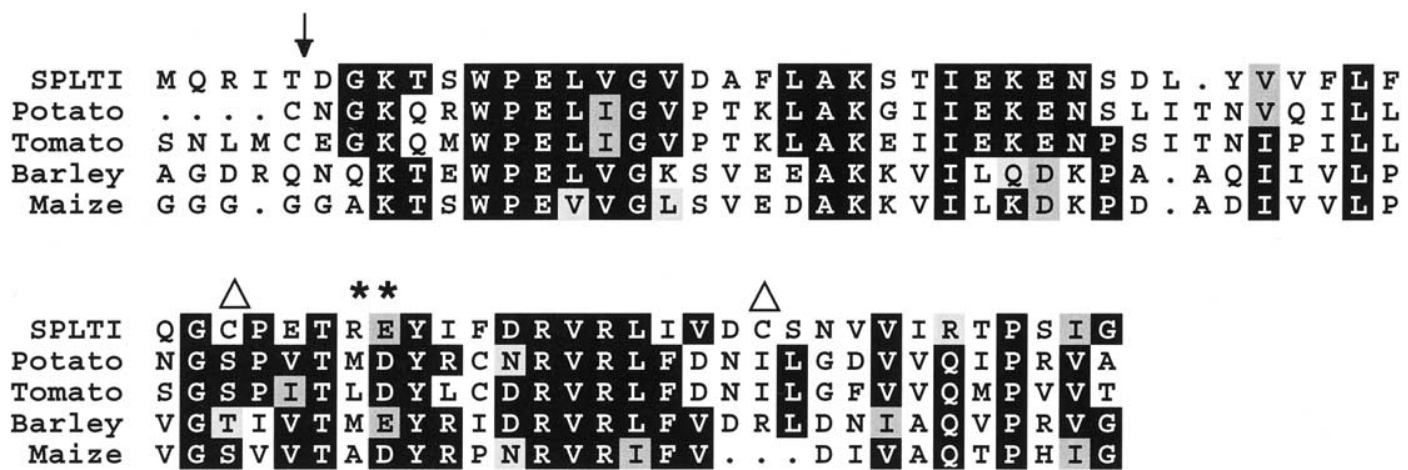

Fig. 3. Alignment of the putative SPLTI amino acid sequence with other members of PI-I family. The deduced amino acid sequence of SPLTI- $a$ was aligned with potato wound-induced proteinase inhibitor I precursor (GenBank accession number P08454), tomato wound-induced proteinase inhibitor I precursor (GenBank accession number P05118), barley chymotrypsin inhibitor (CI-2, GenBank accession number S18818) and maize proteinase inhibitor (MPI, GenBank accession number CAA55588). Identical and similar amino acids were marked with a black background and a gray background, respectively. The vertical arrow indicates the putative processing site to give the mature protein. The putative reactive site of SPLTI was marked with asterisks and the Cys residues were marked with the hollow triangles.

Table 1

The proteinase inhibitory activities of recombinant SPLTI

\begin{tabular}{lll}
\hline & $\begin{array}{l}\text { Trypsin } \\
\left(\mathrm{OD}_{410} \text { arbi- }\right. \\
\text { trary unit })\end{array}$ & $\begin{array}{l}\text { Chymotrypsin } \\
\left(\mathrm{OD}_{410} \text { arbitrary }\right. \\
\text { unit })\end{array}$ \\
\hline $\begin{array}{l}\text { Original relative activity } \\
\begin{array}{l}\text { Residual relative activity after } \\
\text { addition of recombinant SPLTI }\end{array}\end{array}$ & $0.610(100 \%)$ & $0.363(100 \%)$ \\
$\%$ inhibition by recombinant & $67 \%$ & $0.362(99 \%)$ \\
SPLTI & & $1 \%$ \\
\hline
\end{tabular}

The recombinant SPLTI ( $9 \mathrm{nM}$ in monomer), purified with a glutathione-Sepharose-4B affinity column and excised from GSTSPLTI fusion proteins after thrombin digestion, was assayed against trypsin ( $9 \mathrm{nM}$ in monomer) and chymotrypsin ( $9 \mathrm{nM}$ in monomer) at least in duplicate determination.

in length and all encode a 70-amino acids polypeptide with molecular mass of $7.3 \mathrm{kDa}$. Except the additional five residues, MQRIT, at the N-terminus, the deduced amino acid sequence agreed with the $\mathrm{N}$-terminal sequencing analysis by Edman degradation (Fig. 2A). The deduced amino acid sequences of SPLTI- $a$, SPLTI- $b$, gSPLTI-1 and $g$ SPLTI-2 were $98 \%$ identical with each other. These proteins are similar to the PI-I family of serine PIs superfamily found in various plant species. The SPLTI shared similarity to wound-induced PI-Is from potato and tomato (5 0\%), MPI from maize (49\%) and CI-2 from barley (42\%). Multiple alignment of homologous PI-I proteins revealed that two motifs, WPELVG and DRVRL, were conserved across the PI-I family (Fig. 3), which were assumed to be built up of two $\beta$-strands connected by a loop region of SPLTI by our molecular modeling analysis (unpublished data).

\subsection{The Arg-Glu motif is the reactive site that specifically confers the trypsin-inhibitory activity of SPLTI}

We predicted that $\mathrm{Arg}^{46}-\mathrm{Glu}^{47}$ might be the putative reactive site of SPLTI based on the location of these residues relative to the other known members of PI-I family, in which Met-Asp, Leu-Asp, Met-Glu or AlaAsp were reported as the reactive site (Fig. 3). However, the putative reactive site of SPLTI was different. Since we identified SPLTI by activity staining as a trypsin inhibitor rather than a chymotrypsin inhibitor shown by most members of PI-I family, we carried out the proteinase-inhibitory activity assay from the purified recombinant SPLTI overexpressed in E. coli for obtaining further evidence. The recombinant SPLTI was shown in vitro with trypsin-inhibitory activity (Table 1). To test whether the $\mathrm{Arg}^{46}-\mathrm{Glu}^{47}$ motif was respon-

Fig. 2. (A) Nucleotide sequence of SPLTI- $a$ cDNA from sweet potato (Ipomea batatas Lam.). The deduced amino acid sequence is shown below the nucleotide sequence. Stop codon is indicated with asterisk. The dashed line indicates the amino acids determined from partially purified SPLTI by Edman degradation analysis. The vertical arrow indicates the putative site of processing to give the mature protein. The putative polyadenylation signal sequence is underlined. (B) Alignment of the nucleotide sequences of the two SPLTI cDNA clones and two genomic clones from sweet potato. The putative intron regions of the genomic clones were shown in lowercase letters. The start codon, stop codon and the putative polyadenylation signal sequences were underlined. Asterisks $\left(^{*}\right)$ indicate the nucleotide sequence variations. 

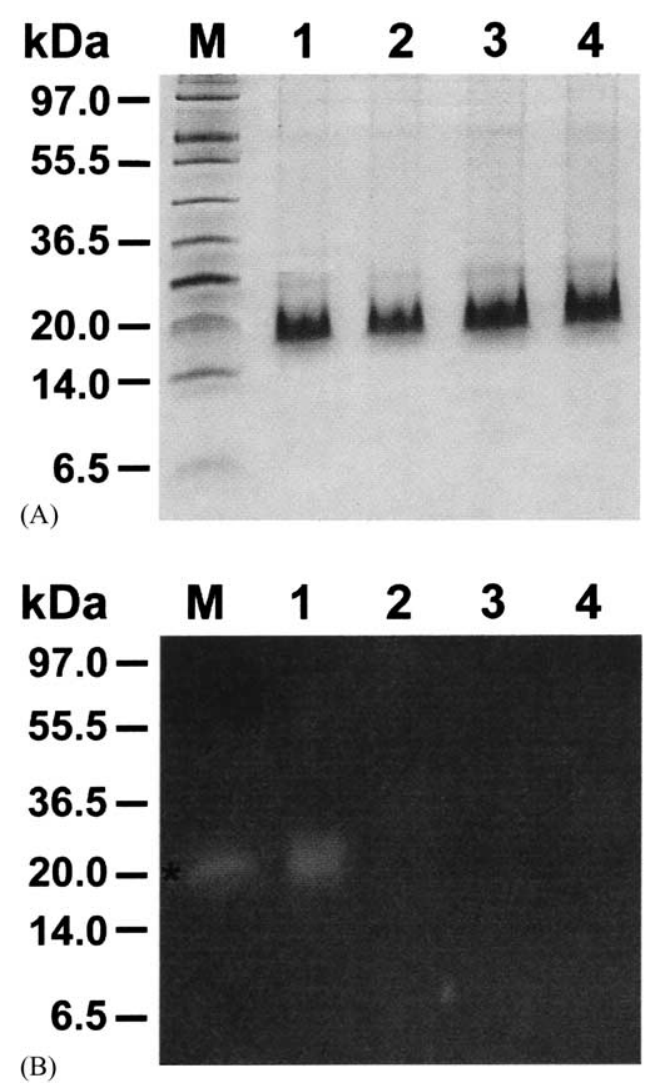

Fig. 4. Trypsin-inhibitory activity analysis of recombinant SPLTI after site-directed mutagenesis. The putative reactive site ( $\mathrm{Arg}^{46}$ $\mathrm{Glu}^{47}$ ) of SPLTI was mutated by site-directed mutagenesis. Recombinant SPLTI proteins $(15 \mu \mathrm{g})$ purified from E. coli were analyzed in duplicate on $13.3 \%$ Tricine-SDS-PAGE gels. (A) Coomassie Brilliant Blue R-250 staining gel. Lane 1, native recombinant SPLTI; lane 2, $\mathrm{R} 46 \mathrm{M}$ mutant $\left(\mathrm{Arg}^{46} \rightarrow \mathrm{Met}^{46}\right.$ ) of recombinant SPLTI; lane 3, E47K mutant $\left(\mathrm{Glu}^{47} \rightarrow \mathrm{Lys}^{47}\right)$ of recombinant SPLTI; lane 4, R46M/E47D $\left(\mathrm{Arg}^{46}-\mathrm{Glu}^{47} \rightarrow \mathrm{Met}^{46}-\mathrm{Lys}^{47}\right)$ double mutant of recombinant SPLTI. M, protein molecular markers (BioLabs, MA). (B) Trypsin-inhibitory activity staining gel of recombinant SPLTI as described above. The $21.5-\mathrm{kDa}$ band of protein marker is soybean trypsin inhibitor, which serves as an activity staining control. Molecular mass was indicated at left side of each panel.

sible for the trypsin-inhibitory activity of SPLTI, the residues were altered from $\mathrm{Arg}^{46}$ to $\mathrm{Met}^{46}$ or from $\mathrm{Glu}^{47}$ to $\mathrm{Lys}^{47}$, and also from $\mathrm{Arg}^{46}-\mathrm{Glu}^{47}$ to $\mathrm{Met}^{46}-\mathrm{Lys}^{47}$ by site-directed mutagenesis. As shown in Fig. 4A, the purified recombinant SPLTI proteins from E. coli were separated on $13.3 \%$ Tricine-SDS-PAGE. The trypsininhibitory activity was abolished in the mutated SPLTI recombinant proteins (Fig. 4B, lanes 2-4). As a result, we believe that the $\mathrm{Arg}^{46}-\mathrm{Glu}^{47}$ motif is important for the trypsin-inhibitory activity of SPLTI.

\subsection{The SPLTIS are regulated in a developmental and organ-specific manner under water-deficit stress}

The expression patterns of SPLTI in different organs of sweet potato were analyzed by RNA blot hybridiza-

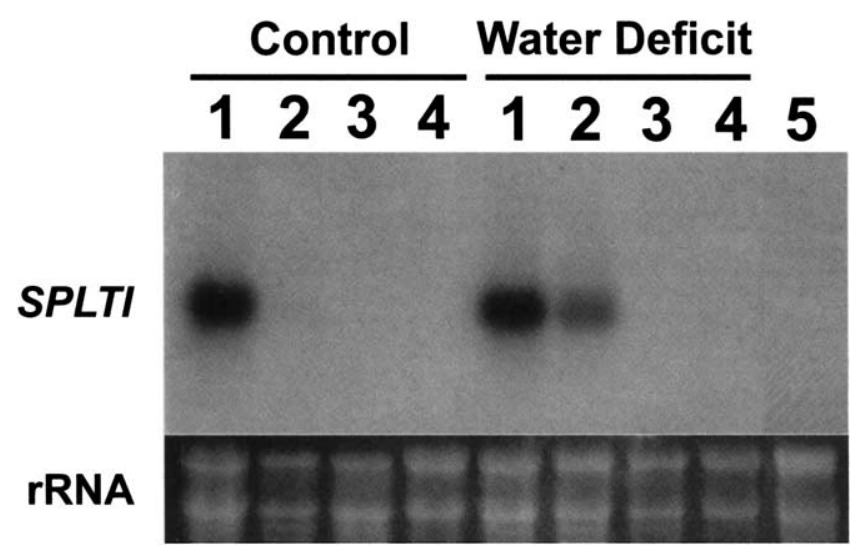

Fig. 5. RNA blot analysis of SPLTI gene expression from different organs of sweet potato under water deficiency for 5 days. Five micrograms of total RNA were loaded on each lane, using the SPLTI- $a$ as a probe. Lane 1, unexpanded young leaf; lane 2, fully expanded mature leaf; lane 3, stem; lane 4, root; lane 5, tuber. rRNA stained with ethidium bromide is shown for equal loading of RNA in each lane.

tion using $S P L T I-a$ cDNA as a probe. As shown in Fig. 5 , the SPLTI transcripts were detected in unexpanded young leaves from control growth condition. It indicated that the SPLTI was constitutively expressed in the young developing leaves. In contrast, the transcripts were found in fully expanded mature leaves only under water deficiency. Therefore, the expression of SPLTI could be under developmental control in the leaf as well as under water deficit stress. We failed to detect the SPLTI transcripts in the stem, root, and tuber of sweet potato under water deficiency by RNA blot analysis (Fig. 5, lanes 3-5). In our knowledge, the SPLTI is the first member of PI-I family up-regulated by water deficiency with leaf-specificity.

\subsection{Effects of environmental stresses on SPLTI mRNAs accumulation}

As described above, SPLTIS were induced in the fully expanded mature leaves of sweet potato under water deficiency. It is interesting to know whether other conditions leading to water deficiency, such as osmoticant, low temperature, heat shock, and salinity could induce the accumulation of SPLTI transcripts. As shown in Fig. 6A, chilling stress, but not heat shock treatment, induced very high levels of SPLTI transcripts. The osmotic stresses i.e. PEG, sorbitol or high salt treatments also showed high levels of SPLTI gene expressions. In our knowledge, this is also the first report that the PI-I genes were induced by chilling stress. 
(A)

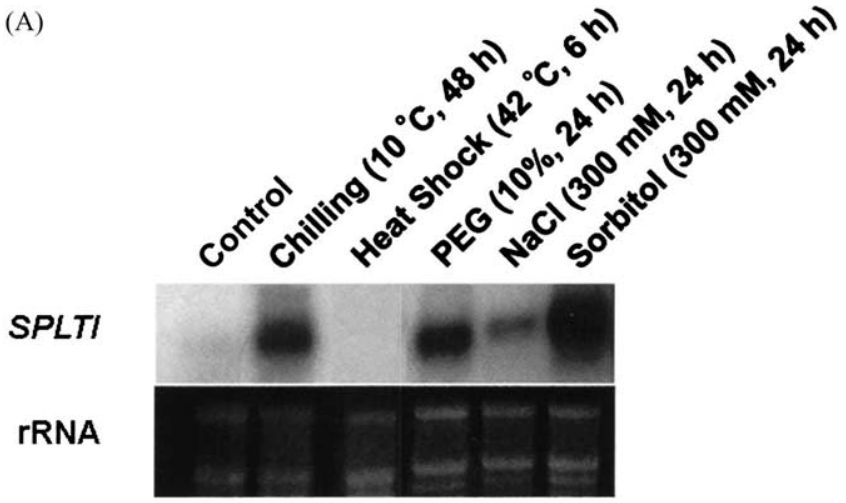

(B)

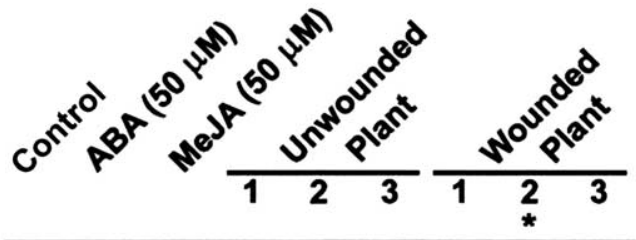

SPLTI

rRNA

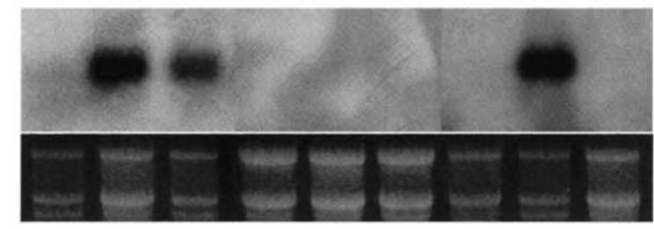

Fig. 6. RNA blot analysis of SPLTI gene expression under environmental stresses. (A) SPLTI gene expression under chilling, osmoticants and heat shock treatments. (B) SPLTI gene expression under plant hormones (ABA or MeJA) treatments and mechanical wounding. Lane 1, 2, and 3 represent the unwounded upper leaf, wounded leaf (indicated by an asterisk) and the unwounded lower leaf of wounded plants, respectively. Five micrograms of total RNA were loaded on each lane, using the SPLTI- $a$ as a probe. rRNA stained with ethidium bromide is shown for equal loading of RNA in each lane.

\subsection{The SPLTI transcripts expressed in a local manner instead of a systemic manner in response to mechanical wounding}

Signal transduction pathway in the systemic wound response for synthesis of $P I$ genes has been studied extensively $[11,13,32]$. The plant hormones ABA and JA have been demonstrated to be the essential signaling components for the activation of $P I$ genes in response to wounding systemically [33-36]. In our study treatment of ABA or MeJA induced the accumulation of SPLTI transcripts in sweet potato leaves (Fig. 6B). However, in contrast to the $P I-I$ genes that expressed systemically in response to mechanical wounding, the SPLTI transcripts accumulated locally in the injured leaves, but there was no signal detected in the unwounded leaves after $6 \mathrm{~h}$ of wound treatment (Fig. 6B). Therefore, the SPLTI genes were induced by mechanical wounding as shown in potato, tomato and maize, but its expression was local instead of systemic.

\subsection{The relationship of $R W C$ with the accumulation of SPLTI transcripts}

Since the RWC of leaf could indicate the extent of dehydration, we measured the RWC of the leaves to find the relationship between the RWC and SPLTI transcript levels. In the dehydration/rehydration treatments, SPLTI transcript levels were clearly associated with RWC fluctuation in the leaf tissue (Fig. 7). It is noticeable that the patterns of the gene expression and the fluctuation of RWC in response to dehydration/ rehydration treatments were different in the two developmental stages of leaves. Fig. 7A shows that SPLTI transcripts reached to the highest level in the fully expanded leaf by day 3 of water deficit treatment, and then the transcripts decreased gradually to disappear by day 5 of rehydration treatment. However, the lowest level of RWC was detected on day 5 of water deficiency. On the other hand, Fig. 7B shows that the gene expression in the unexpanded young leaves was enhanced by day 1 of water deficiency and maintained at high-level during water deficit period. These results suggested that SPLTI gene expression was transient in response to water deficiency in fully expanded mature leaves, but the response was fast and constitutive in the unexpanded young leaves.

\section{Discussion}

The identification of PI-I genes and the analysis of their expression patterns in response to various stresses have provided improved understanding of the roles of $P I-I$ genes in stress adaptation in higher plants. In this paper, we reported the isolation, characterization and expression analysis of a novel sweet potato gene (SPLTI) family encoding serine PIs of PI-I family. The SPLTI cDNAs reported here are 432 bp in length and each contains a complete ORF encoding a putative small polypeptide of 70 amino acids (Fig. 3). Comparing with the N-terminal sequencing result of SPLTI protein, the predicted polypeptides contain extra 5 additional residues at the $\mathrm{N}$-terminus (Fig. 3). It is well known that the short $\mathrm{N}$-terminal targeting sequence could be involved in sorting and targeting of some seed storage proteins [37]. Most members of PI-I family are found in storage organs of higher plants, however, the SPLTI is a leaf specific PI-I protein and its subcellular localization remains unknown. The reactive site of SPLTI is $\mathrm{Arg}^{46}$ $\mathrm{G} 1 \mathrm{u}^{47}$ and this motif was confirmed to be required for the trypsin-inhibitory activity of SPLTI in vitro (Fig. 4 and Table 1). It has long been postulated that the PIs interacted with the proteinases via a specific reactive peptide bond $\mathrm{P}_{1}-\mathrm{P}_{1}^{\prime}$, which is situated within a loop region bridged by a disulfide bond [7]. The amino acid residues of reactive sites in PIs have higher substitution 

Treated Plant

Control Plant

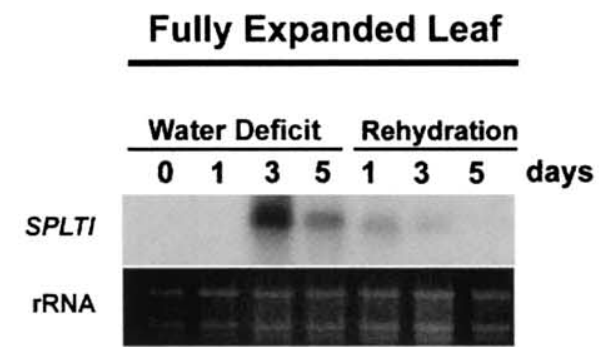

\section{RWC}

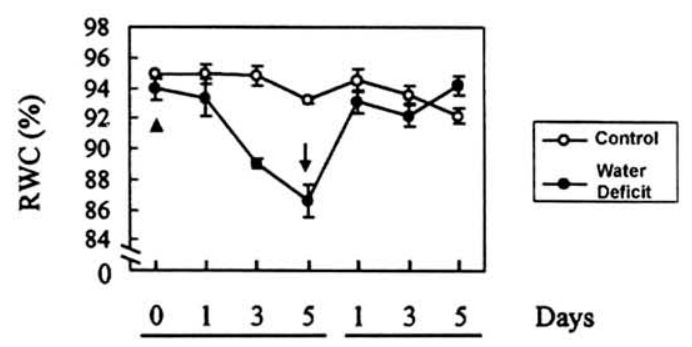

(B) Unexpanded Young Leaf

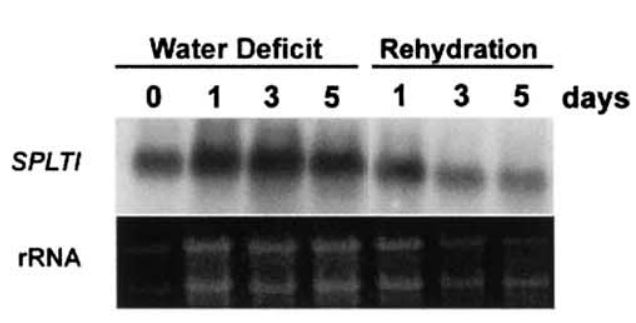

SPLTI

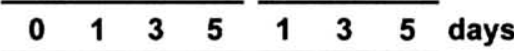

rRNA

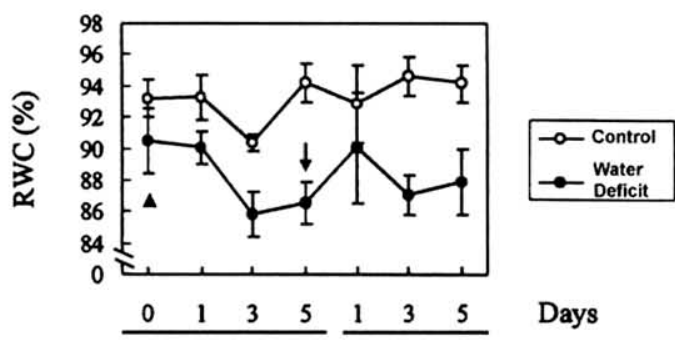

Fig. 7. RNA blot analysis of SPLTI gene expression in relationship to RWC under water deficiency and rehydration treatments in sweet potato leaves. (A) SPLTI gene expression in fully expanded mature leaf. (B) SPLTI gene expression in unexpanded young leaf. The numbers ( $0,1,3$, and 5) indicate the time interval (day) for harvesting samples and measurement of RWC. Day 0 represents the onset of water deficiency. 'Treated plant' represents the plants under water deficiency and rehydration treatments. 'Control plant' is the plants incubated under control growth conditions. 'RWC' indicates the fluctuation of RWC in treated and control leaves of sweet potato plants. Five micrograms of total RNA were loaded on each lane and SPLTI- $a$ cDNA was used as a probe. rRNA stained with ethidium bromide is shown for equal loading of RNA in each lane. Arrowhead on day 0 indicates the onset of water deficiency. Arrow indicates the day of rehydration.

than the rest of amino acid residues in the PI molecules [15], and its specificity shows extensive variation at the $\mathrm{P}_{1}$ site of the target proteinases [38]. There are several reactive sites identified in the PI-I family, such as MetAsp [7], Leu-Asp [7], Met-Glu [4], Leu-Asn [4], AlaAsp [39], and Lys-Asp [15]. Most of the $P_{1}$ sites consist of hydrophobic amino acids, however, $\mathrm{P}_{1}$ site with a basic polar residue of lysine provides trypsin inhibitor specificity to PI-Is $[15,40,41]$. Our analyses of SPLTI reactive site agreed with that of PI-Is and exhibited a new residue for the trypsin inhibitor specificity. The activity-staining assay of SPLTI showed a 14-kDaprotein band; however, a major 7-kDa-protein band was presented on the denatured SDS-PAGE (Fig. 1). These results indicated that an intermolecular disulfide bridge might be involved in the stability of SPLTI. Two cysteine residues, $\mathrm{C}^{42}$ and $\mathrm{C}^{59}$, were further shown to be involved in the intermolecular disulfide bridge formation and for stability of SPLTI in vivo by site-directed mutagenesis analysis (unpublished data). From these results, we believe that the SPLTI represents a novel type of PI-I protein in higher plants.

The SPLTI genes were responsive to ABA and MeJA treatments (Fig. 6B). It is well known that MeJA, a signal molecule, is released from plants under various stresses, such as wounding, pathogen attack, fungal elicitors, osmosis and drought [42]. A lot of evidence showed that JA and its derivatives could activate PI-I genes in plants $[11,13,32]$. In the systemic wound response, the primary signal systemin was released at the wound site and subsequently activate the synthesis of JA both in wounded and unwounded leaves [11]. The systemic PI-I accumulations have been observed in potato, tomato and maize $[5,16,43,44]$. However, the expression of SPLTI genes was detected rather locally (Fig. 6B). The lack of systemic wound response of PI-I gene was also observed in tobacco [45]. It has been suggested that tobacco do not contain the proper cisacting elements necessary for responding to the systemic signaling pathway [45]. The hypothesis could be further 
supported by the promoter activity assay of SPLTI gene in transgenic Arabidopsis. It showed that the wound response was restricted at the wound sites, but not systemically (unpublished data).

The distinctive feature of SPLTI genes among PI-I family is the regulation of their expressions by water deficiency, chilling and salt stresses in addition to mechanical wounding. The versatile regulation of SPLTI genes is the consequence of transcriptional activation since the presence of the cis-elements responsive to the stresses described above in the promoter regions of SPLTI genes (unpublished data). Example of gene expression regulated by multiple environmental stimuli has also been found in leucine aminopeptidase [36], which was responsive to ABA and MeJA treatments, as well as to mechanical wounding, osmotic, and chilling stresses. The leucine aminopeptidase has been predicted to play a defensive role in response to wounding and drought stress [36]. Therefore, a crosstalk between the octadecanoid and abiotic-stress signal transduction pathways was proposed for the coordinated gene expressions [36]. Our results raise the possibility that the expressions of SPLTI genes, at least some members of the gene family, are regulated in a similar manner.

PI-I proteins are usually thought to play a defensive role in higher plants, probably owing to the fact that the gene products are induced rapidly in response to mechanical wounding and are abundant in storage organs. How PI-I proteins protect plants from unfavorable conditions is still unclear. Evidence showed that PIs regulated the endogenous proteolytic activity when plants were under water deficiency [20,22]. Furthermore, a PI-I protein, AmTI, was proposed to regulate the endogenous proteolytic activities during the development of stems and seeds under control growth conditions [37]. Therefore, we assumed that the activation of SPLTI expression might reflect the regulation of proteolytic processes in the sweet potato leaves for recovery from unfavorable environments. It is noteworthy that accumulation of SPLTI transcripts was regulated differentially between the unexpanded young leaves and fully expanded mature leaves (Fig. 5 and Fig. 7). It suggested that the constitutive presence of SPLTI transcripts in unexpanded young leaves may allow the leaves a rapid response to water deficiency. In addition, in the expanded mature leaves, SPLTI gene expression was only responsive to mild decrease of RWC, suggesting that SPLTI may play an early role in response to water deficiency in sweet potato leaves.

The proteins responsible for the synthesis of compatible solutes and scavenging reactive oxygen species, as well as water channels, ion transporters, and protective proteins, are involved in plant response to salt or water deficiency [46,47]. Transgenic plants overexpressing these genes revealed higher tolerance to osmotic or freezing stress than control plants [48]. Osmotin, a protein that is induced by water deficiency and salinity, has also been shown to confer fungal resistance to plants under water deficiency [49]. However, what the physiological significance of the versatile regulation of SPLTI genes remains unclear. The transgenic plants of SPLTI genes will be helpful to our understanding of the function of the SPLTI gene in the stress tolerance of sweet potato plants.

\section{Acknowledgements}

We appreciate Dr Lu-Ping Chow, for her technical service on $\mathrm{N}$-terminal sequence determination. We are also grateful to Dr Chu-Yung Lin for his critical reading and helpful suggestions in revising this manuscript. This work was supported in part by National Science Council, Taiwan, ROC under the grants of NSC-892311-B-002-055 to Dr Kai-Wun Yeh.

\section{References}

[1] M. Richardson, Seed storage proteins: the enzyme inhibitors, Methods Plant Biochem. 5 (1991) 259-305.

[2] S. Valdés-Rodríguez, M. Segura-Nieto, A. Chagolla-López, A. Verver y Vargas-Cortina, N. Martinez-Gallardo, A. BlancoLabra, Purification, characterization, and complete amino acid sequence of a trypsin inhibitor from amaranth (Amaranthus hypochondriacus) seeds, Plant Physiol. 103 (1993) 1407-1412.

[3] J.C. Melville, C.A. Ryan, Chymotrypsin inhibitor I from potatoes: a multi-site inhibitor composed of subunits, Arch. Biochem. Biophys. 138 (1970) 700-702.

[4] I. Svendsen, I. Jonassen, J. Hejgaard, Amino acid sequence homology between a serine protease inhibitor from barley and potato Inhibitor I, Carlsberg Res. Commun. 45 (1980) 389-395.

[5] M.J. Cordero, D. Raventós, B.S. Segundo, Expression of a maize proteinase inhibitor gene is induced in response to wounding and fungal infection: systemic wound-response of a monocot gene, Plant J. 6 (1994) 141-150

[6] Y.E. Dunaevsky, E.B. Pavlukova, G.A. Beliakova, T.A. Tsybina, T.N. Gruban, M.A. Belozersky, Proteinase inhibitors in buckwheat seeds: comparison of anionic and cationic inhibitors, J. Plant Physiol. 152 (1998) 696-702.

[7] M. Richardson, The proteinase inhibitors of plants and microorganisms, Phytochemistry 16 (1977) 159-169.

[8] C.A. Ryan, Proteinase inhibitor gene families: strategies for transformation to improve plant defenses against herbivores, BioEssays 10 (1989) 20-24.

[9] C.P Constabel, A survey of herbivore-inducible defensive proteins and phytochemicals, in: A.A. Agrawal, S. Tuzun, E. Bent (Eds.), Induced Plant Defenses Against Pathogens and HerbivoresBiochemistry, Ecology, and Agriculture, The American Phytopathological Society, APS Press, USA, 1999, pp. 137-166.

[10] K. W. Yeh, J.C. Chen, M.I. Lin, Y.M. Chen, C. Y. Lin, Functional activity of sporamin from sweet potato (Ipomoea batatas Lam.): a tuber storage protein with trypsin inhibitory activity, Plant Mol. Biol. 33 (1997) 565-570.

[11] C.A. Ryan, The systemin signaling pathway: differential activation of plant defensive genes, Biochim. Biophys. Acta 1477 (2000) $112-121$. 
[12] C.A. Ryan, Protease inhibitors in plants: genes for improving defenses against insects and pathogens, Annu. Rev. Phytopathol. 28 (1990) 425-449.

[13] H. Koiwa, R.A. Bressan, P.M. Hasegawa, Regulation of protease inhibitors and plant defense, Trends Plant Sci. 2 (1997) 379-384.

[14] L.L. Beuning, T.W. Spriggs, J.T. Christeller, Evolution of the proteinase inhibitor I family and apparent lack of hypervariability in the proteinase contact loop, J. Mol. Evol. 39 (1994) 644-654.

[15] V.P.M. Wingate, R.M. Broadway, C.A. Ryan, Isolation and characterization of a novel, developmentally regulated proteinase inhibitor I protein and cDNA from the fruit of a wild species of tomato, J. Biol. Chem. 264 (1989) 17734-17738.

[16] T.R. Green, C.A. Ryan, Wound-induced proteinase inhibitor in plant leaves: a possible defense mechanism against insects, Science 175 (1972) 776-777.

[17] J.S. Graham, G. Hall, G. Pearce, C.A. Ryan, Regulation of synthesis of proteinase inhibitors I and II mRNAs in leaves of wounded tomato plants, Planta 169 (1986) 399-405.

[18] G. Pearce, D. Strydom, S. Johnson, C.A. Ryan, A polypeptide from tomato leaves induces wound-inducible proteinase inhibitor proteins, Science 253 (1991) 895-898.

[19] A. Schaller, C.A. Ryan, Systemin - a polypeptide defense signal in plants, BioEssays 18 (1995) 27-33.

[20] W.L. Downing, F. Mauxion, M.-O. Fauvarque, M.-P. Reviron, D. de Vienne, N. Vartanian, J. Giraudat, A Brassica napus transcript encoding a protein related to the Künitz protease inhibitor family accumulates upon water stress in leaves, not in seeds, Plant J. 2 (1992) 685-693.

[21] M.A. Dunn, M.A. Hughes, L. Zhang, R.S. Pearce, A.S. Quigley, P.L. Jack, Nucleotide sequence and molecular analysis of the low temperature induced cereal gene, BLT4, Mol. Gen. Genet. 229 (1991) 389-394.

[22] M. Pernas, R. Sánchez-Monge, G. Salcedo, Biotic and abiotic stress can induce cystatin expression in chestnut, FEBS Lett. 467 (2000) 206-210.

[23] M.A. Schaffer, R.L. Fischer, Analysis of mRNAs that accumulate in response to low temperature identifies a thiol protease gene in tomato, Plant Physiol. 87 (1988) 431-436.

[24] R. Khanna-Chopra, B. Srivalli, Y.S. Ahlawat, Drought induces many forms of cysteine proteases not observed during natural senescence, Biochem. Biophys. Res. Commun. 255 (1999) 324 327.

[25] M.H. Cruz de Carvalho, A. d'Arcy-Lameta, H. Roy-Macauley, M. Gareil, H.E. Maarouf, A.-T. Pham-Thi, Y. Zuily-Fodil, Aspartic protease in leaves of common bean (Phaseolus vulgaris L.) and cowpea (Vigna unguiculata L. Walp): enzymatic activity, gene expression and relation to drought susceptibility, FEBS Lett. 492 (2001) 242-246.

[26] H.Y. Wang, K.W. Yeh, Cultivar differences in trypsin inhibitory activities of sweet potato leaves and tuberous roots, Taiwania 41 (1996) 27-34

[27] U.K. Laemmli, Cleavage of structural proteins during the assembly of the head of bacteriophage T4, Nature 227 (1970) $680-685$.

[28] J. Chan, B.O. DeLumex, Properties of trypsin inhibitor from winged bean (Psophocarpus tetragonolobus) seed isolated by affinity chromatography, J. Agric. Food Chem. 30 (1982) 42-46.

[29] H. Schägger, G. von Jagow, Tricine-sodium dodecyl sulfatepolyacrylamide gel electrophoresis for the separation of proteins in the range from 1 to $100 \mathrm{kDa}$, Anal. Biochem. 166 (1987) 368 379.

[30a] J. Sambrook, D.W. Russell, Northern hybridization, in: J. Sambrook, D.W. Russell (Eds.), Molecular Cloning, vol. 1, third ed., Cold Spring Harbor Laboratory Press, 2001, pp. 7.427.45 . [30b] J. Sambrook, D.W. Russell, Mutagenesis, in: J. Sambrook, D.W. Russell (Eds.), Molecular Cloning, vol. 2, third ed., Cold Spring Harbor Laboratory Press, 2001, pp. 13.8-13.9.

[31] P.-L. Yao, M.-J. Hwang, Y.-M. Chen, K.-W. Yeh, Site-directed mutagenesis evidence for a negatively charged trypsin inhibitory loop in sweet potato sporamin, FEBS Lett. 496 (2001) 134-138.

[32] E.E. Farmer, C.A. Ryan, Octadecanoid precursors of jasmonic acid activate the synthesis of wound-inducible proteinase inhibitors, Plant Cell 4 (1992) 129-134.

[33] H. Peña-Cortés, J.J. Sánchez-Serrano, R. Mertens, L. Willmitzer, S. Prat, Abscisic acid is involved in the wound-induced expression of the proteinase inhibitor II gene in potato and tomato, Proc. Natl. Acad. Sci. USA 86 (1989) 9851-9855.

[34] H. Peña-Cortés, J. Fisahn, L. Willmitzer, Aspirin prevents wound-induced gene expression in tomato leaves by blocking jasmonic acid synthesis, Planta 191 (1993) 123-128.

[35] H. Peña-Cortés, S. Prat, R. Atzorn, C. Wasternack, L. Willmitzer, Abscisic acid-deficient plants do not accumulate proteinase inhibitor II following systemin treatment, Planta 198 (1996) 447-451.

[36] W.S. Chao, Y.-Q. Gu, V. Pautot, E.A. Bray, L.L. Walling, Leucine aminopeptidase RNAs, proteins, and activities increase in response to water deficit, salinity and the wound signals systemin, methyl jasmonate, and abscisic acid, Plant Physiol. 120 (1999) 979-992.

[37] S. Valdés-Rodríguez, A. Blanco-Labra, G. Gutierrez-Benicio, A. Boradenenko, A. Herrera-Estrella, J. Simpson, Cloning and characterization of a trypsin inhibitor cDNA from amaranth (Amaranthus hypochondriacus) seeds, Plant Mol. Biol. 41 (1) (1999) 15-23.

[38] I. Schecter, A. Berger, On the size of the active site in proteases. I. Papain, Biochem. Biophys. Res. Commun. 27 (1967) 157-162.

[39] I. Svendsen, J. Hejgaard, J.K. Chavan, Subtilisin inhibitor from seeds of broad bean (Vicia faba); purification, amino acid sequence and specificity of inhibition, Carlsberg Res. Commun. 49 (1984) 493-502.

[40] R. Krishnamoorthi, Y.X. Gong, M. Richardson, A new protein inhibitor of trypsin and activated Hageman factor from pumpkin (Cucurbita maxima) seeds, FEBS Lett. 273 (1990) 163-167.

[41] K.R. Roesler, A.G. Rao, Conformation and stability of barley chymotrypsin inhibitor-2 (CI-2) mutants containing multiple lysine substitutions, Protein Eng. 12 (11) (1999) 967-973.

[42] S. Reinbothe, B. Mollenhauer, C. Reinbothe, JIPs and RIPs: the regulation of plant gene expression by jasmonates in response to environmental cues and pathogens, Plant Cell 6 (1994) $1197-$ 1209.

[43] G. Plunkett, D.F. Senear, G. Zuroske, C.A. Ryan, Proteinase inhibitor I and II from leaves of wounded tomato plants: purification and properties, Arch. Biochem. Biophys. 213 (1982) $456-462$.

[44] M.C. Tamayo, M. Rufat, J.M. Bravo, B.S. Segundo, Accumulation of a maize proteinase inhibitor in response to wounding and insect feeding, and characterization of its activity toward digestive proteinases of Spodoptera littoralis larvae, Planta 211 (2000) 6271.

[45] H.J.M. Linthorst, F.T. Brederode, C. van der Does, J.F. Bol, Tobacco proteinase inhibitor I genes are locally, but not systemically induced by stress, Plant Mol. Biol. 21 (1993) 985992.

[46] D. Bartels, Late embryogenesis abundant (LEA) proteins: expression and regulation in the resurrection plant Craterostigma plantagineum, in: M.F. Smallwood, C.M. Calvert, D.J. Bowles (Eds.), Plant Responses to Environmental Stress, first ed., BIOS Scientific Publishers, Oxford, UK, 1999, pp. 153-160.

[47] K. Shinozaki, K. Yamaguchi-Shinozaki, Q. Liu, M. Kasuga, K. Ichimura, T. Mizoguchi, T. Urao, S. Miyata, K. Nakashima, Z.K. Shinwari, H. Abe, Y Sakuma, T. Ito, M. Seki, Molecular 
responses to drought stress in plants: regulation of gene expression and signal transduction, in: M.F. Smallwood, C.M. Calvert, D.J. Bowles (Eds.), Plant Responses to Environmental Stress, first ed., BIOS Scientific Publishers, Oxford, UK, 1998, pp. 133-143.
[48] N. Holmberg, L. Bulow, Improving stress tolerance in plants by gene transfer, Trends Plant Sci. 3 (2) (1998) 61-66.

[49] E.A. Bray, Molecular responses to water deficit, Plant Physiol. 103 (1993) 1035-1040. 